\title{
The Effect of Fly Ash as a Part Cement Institution on High Quality Concrete FC'35
}

\author{
Herlinawati ${ }^{1, *}$ Sazili Harnawansyah ${ }^{1}$ Bastoni Hasasi $^{1}$ Radius Pranoto $^{1}$ \\ ${ }^{1}$ Civil Engineering Departement, Sriwijaya State Polytechnic, Palembang, 30154, Indonesia \\ ${ }^{*}$ Corresponding author.Email: herlinawati@polsri.ac.id
}

\begin{abstract}
The development of science and technology, many research has been done on high-quality concrete to overcome the shortcomings of ordinary concrete. To reduce the porosity of the cement, mineral added materials that are pozzolanic and have very fine particles can be used. One of the mineral added materials is fly ash (Fly Ash). The size and size of the porosity are also influenced by the size and size of the FAS (cement water factor) which is used to facilitate work (workability) and increase the compressive strength of concrete. This research was conducted to determine the effect of partial replacement of cement with Fly Ash on the compressive strength of concrete. The composition of cement replacement with various Fly Ash variations is $0 \%, 6 \%, 8 \%$, and $10 \%$ of the weight of cement. The sample used is cylindrical, the quality of the concrete is $35 \mathrm{MPa}$, planned for 28 days. Samples were tested at 7 days, 14 days, 21 days, and 28 days with treatment before compressive strength testing. The total sample size was 48 samples consisting of 4 variations and each variation consisting of 12 samples.
\end{abstract}

Keywords: Fly ash, cement, compressive, concrete.

\section{INTRODUCTION}

The construction of building construction in Indonesia has grown rapidly in line with the increasing population, especially in big cities which have resulted in an increasing need for facilities and infrastructure, particularly roads, bridges, houses, and buildings. In general, most of the existing facilities and infrastructure (infrastructure) use concrete construction, where the implementation is known by most of the community. Concrete can still meet the needs for construction and overall concrete construction is still considered cheaper than other constructions. The development of science and technology, a lot of research has been done on high strength concrete to overcome the shortcomings of ordinary concrete. Currently, high-quality concrete is widely used in the construction sector of high-rise buildings, dams, bridges with long spans, and so on. Among the most important concrete properties are the compressive strength and the quality of concrete. Based on its compressive strength, concrete quality is broadly divided into ordinary-strength concrete, high strength concrete, and very high strength concrete. One of the problems that greatly affect the compressive strength of concrete is porosity. Porosity can be caused by the presence of relatively large particles of concrete so that the density cannot be maximized. The smallest particle of conventional concrete is cement. To reduce the porosity of the cement, mineral added materials that are pozzolanic and have very fine particles can be used. One of the mineral added materials is fly ash (Fly Ash). Fly Ash is the residue from the coal burning process that comes out of the furnace of the Steam Power Plant (PLTU). The purpose of this study are as follows: to get a high-quality concrete mixture and to get the optimum compressive strength in concrete, use a partial replacement of cement with coal ash.

\section{LITERATURE REVIEW}

The results of the study (Mardiono, 2011), "The Effect of Using Fly Ash in High-Quality Concrete". The planned concrete quality is $40 \mathrm{MPa}$ at the age of 28 days. The results of the calculation show that the cement water factor was obtained at 0.420 and the superplasticizer content was determined to be $1 \%$ of the weight of cement and the results obtained were that the highest concrete compressive strength was found in the cement replacement concrete mixture with $10 \%$ fly ash, which was $41.57 \mathrm{MPa}$ and strong. The lowest concrete press is found in the concrete mixture with fly ash $40 \%$, which is $33.91 \mathrm{MPa}$. It is recommended that further research be 
carried out with different variations of fly ash (the percentage of content is smaller) or combined with other pozzolanic/mineral ingredients and the use of superplasticizers with other levels and types. That by using $10 \%$ fly ash as a partial replacement for cement, a higher compressive strength will be obtained compared to normal concrete. Arifin et. al.(2012) studied fly ash is waste of coal combustion which can be used in aluminum alloy. In his research aluminum is mixed with fly ash that used powder metallurgy method. Then, Danasi and Lisantono, 2015 studied the effect of addition of fly ash to tinggu quality concrete with silica fume and quartz and filler" is to ensure the optimum value of Fly Ash content in high-quality concrete mixtures. The value of the average compressive strength of concrete at 28 days of age with variations in the levels of fly ash $0 \%, 5 \%, 10 \%$, $15 \%, 20 \%, 25 \%$ respectively $37.69 \mathrm{MPa}, 75.06 \mathrm{MPa}$, 64.30 MPa, 60.92 MPa, 58.32 MPa, 66.11 MPa. The highest compressive strength value occurs at a $5 \%$ variation of fly ash content of $75.06 \mathrm{MPa}$ which increases the compressive strength by $99.15 \%$ of concrete without fly ash. The combination of added materials used can increase the compressive strength of the concrete well. Pangestuti et. al., 2018, studied about the use of fly ash as additive material to high strength concrete, from her result concrete 28 days has good compressive strength 45.87 MPa. The percentage of additive sika viscocrete 1003 varies between $0.2 \%, 0.4 \%, 0.6 \%$ taken from the weight of the cement, added with the composition of the normal concrete mixture made in a $10 \times 30$ cylinder specimen with age variations 7, 14, and 28 days. Research using the additive sika viscocrete 1003 resulted in a slump value that was so high the greater the addition the higher the slump value obtained. The value of the compressive strength obtained from the addition of this superplasticizer at the age of 28 days was greater in line with the greater the number of percentage additions given. In the $0.2 \%$ mixture, the compressive strength value is $44.07 \mathrm{MPa}$, a mixture of $0.4 \%$ is $49.84 \mathrm{MPa}$ and a mixture of $0.6 \%$ is $51.96 \%$, from The normal compressive strength of concrete is 42 .

\section{RESEARCH METHODS}

The manufacture of test objects (concrete) and compressive strength testing was carried out at the Material Testing Laboratory (material testing) of the Civil Engineering Department of the Sriwijaya State Polytechnic of Palembang. Material testing is the initial stage of testing before making the concrete mixture. Where in this testing phase consists of several tests, namely: density of aggregate (coarse and fine), the weight of aggregate content (coarse and fine), aggregate sludge content (coarse and fine) aggregate sieve analysis (coarse and fine), fine aggregate organic content, cement consistency test, cement density, cement binding time, and fly ash density. At this stage, mixing of all aggregates that have been tested before, with variations in the composition of the Fly Ash mixture with variations of $0 \%, 6 \%, 8 \%$, and $10 \%$ of the weight of cement. Each variation of the composition makes 3 test objects, each one variation of the test objects is made 4 testing times, namely 7 days, 14 days, 21 days, and 28 days. Compressive strength testing is done every 7 days, 14 days, 21 days, and 28 days. Every time the test is carried out 3 test objects, this is done to find out how much influence Fly Ash has on the compressive strength of the concrete. The compressive strength test is carried out at the Material Testing Laboratory (material testing) of the Civil Engineering Department of the Sriwijaya State Polytechnic.

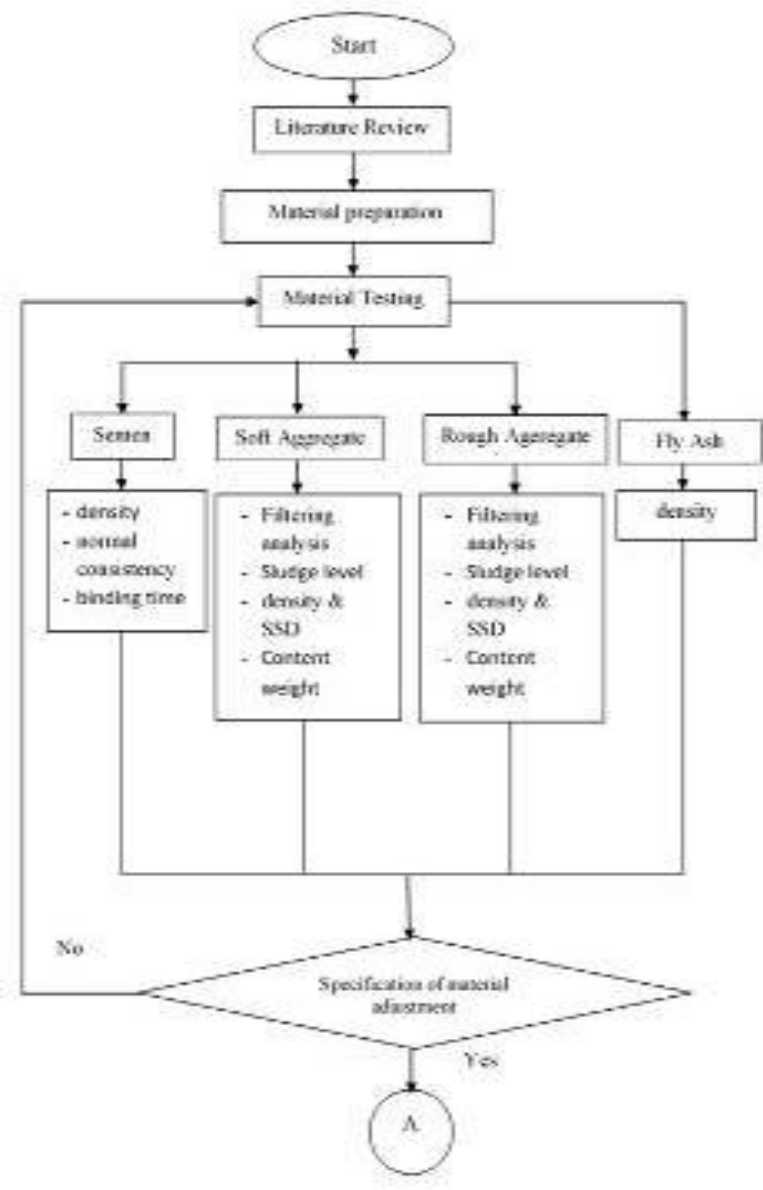




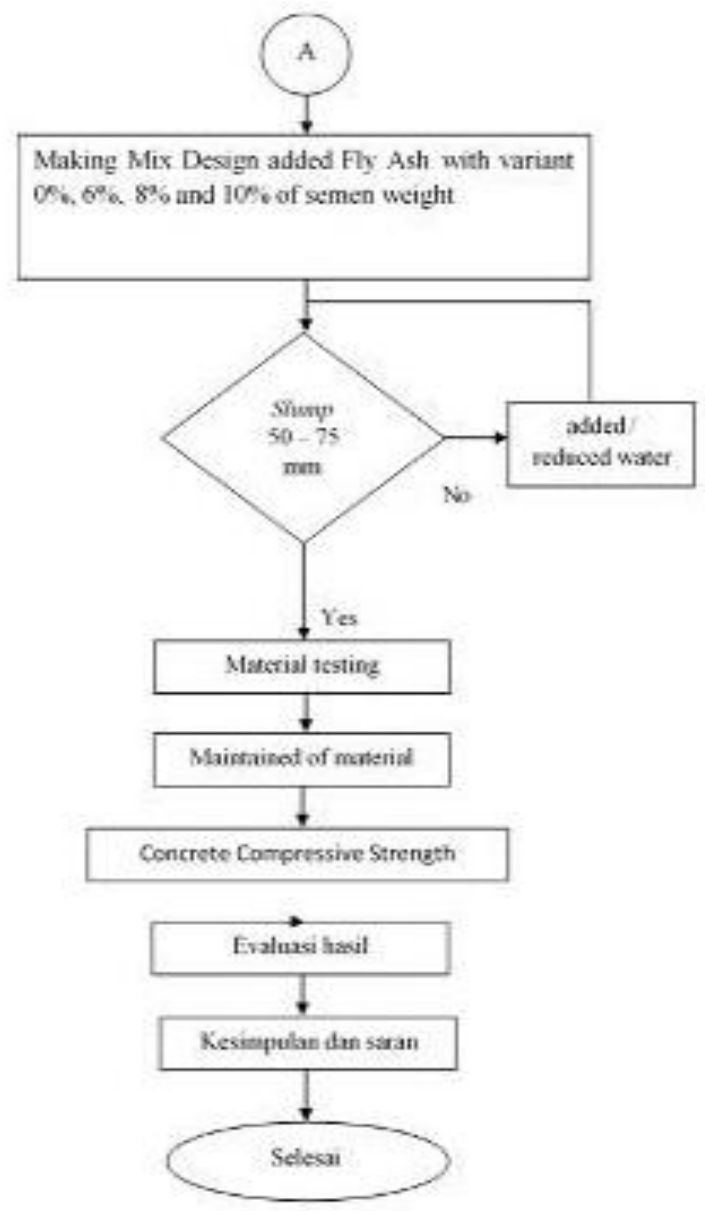

\section{RESULT AND DISCUSSION}

\subsection{Material Testing}

The results of the sieve analysis test that has been carried out in the Civil Engineering Laboratory of Material Testing (Material Testing), the following results are obtained:

Figure 1 Flowchart of Research

Tabel 1. Test Result of Fine Aggregate Sieve Analysis

\begin{tabular}{|c|c|c|c|c|}
\hline \multirow{2}{*}{$\begin{array}{c}\text { Sieve Hole } \\
(\mathrm{mm})\end{array}$} & \multicolumn{2}{|c|}{ Weight Withheld Pass $(\%)$} & \multirow{2}{*}{ Cumulative (\%) } & \multirow{2}{*}{ Pass( \%) } \\
\cline { 2 - 3 } & Gram & $\%$ & 0 & 900 \\
\hline 9,5 & 0 & 0 & 0,25 & 98,75 \\
\hline 4,75 & 2,5 & 0,25 & 1,31 & 95,0 \\
\hline 2,36 & 10,6 & 1,06 & 5,0 & 73,15 \\
\hline 1,18 & 36,9 & 3.69 & 26,85 & 20,03 \\
\hline 0,6 & 218,5 & 21,85 & 79,97 & 1,8 \\
\hline 0,3 & 531,2 & 53,12 & 98,2 & 0 \\
\hline 0,15 & 182,3 & 18,23 & 100 & - \\
\hline Pan & 18 & 1,8 & 211.58 & \\
\hline Total & 1000 & 100 & & \\
\hline
\end{tabular}

Then the value of Aggregate Grain Fine Modulus $(\mathrm{MHB})=\frac{\% \text { comulative }}{100}=\frac{211,58}{100}=2.11$
Based on the results of the fine aggregate sieve analysis test, the MHB value obtained was 2.11 which met the SII 0052 standard, namely between $1.5-3.8$. 


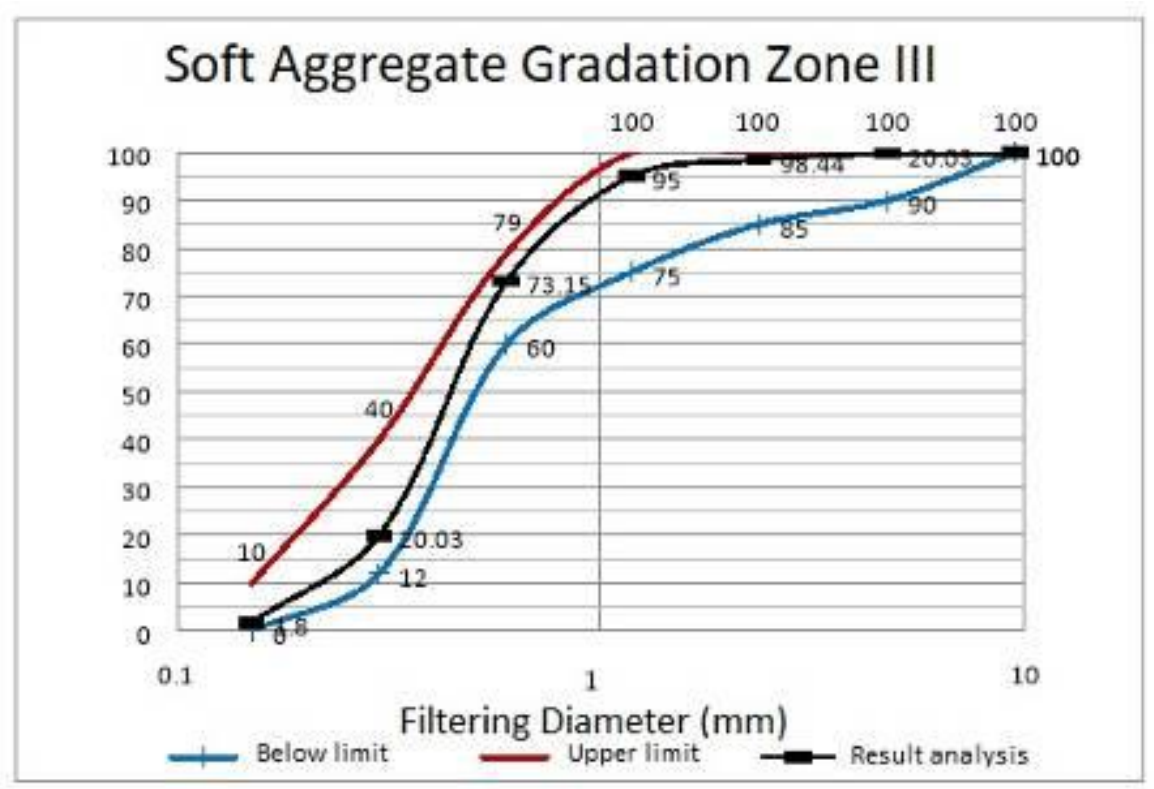

Figure 2 Smooth Aggregate Curve

Table 2 Test Result Coarse Aggregate Sieve Analyisi Size 1/2

\begin{tabular}{|c|c|c|c|c|}
\hline \multirow{2}{*}{$\begin{array}{c}\text { Sieve hole } \\
(\mathrm{mm})\end{array}$} & \multicolumn{2}{|c|}{ Weight Withheld Pass $(\%)$} & \multirow{2}{*}{ Cumulative\% } & \multirow{2}{*}{ Pass( \%) } \\
\cline { 2 - 3 } & $\mathrm{gr}$ & $\%$ & 18,95 & 81,05 \\
\hline 19 & 568,5 & 18,95 & 91,51 & 8,49 \\
\hline 9,5 & 2176,7 & 72,56 & 99,08 & 0,92 \\
\hline 4,75 & 227 & 7,57 & 99,84 & 0,16 \\
\hline 2,36 & 22,7 & 0,76 & 99,84 & 0,16 \\
\hline 1,18 & 0 & 0 & 99,84 & 0,16 \\
\hline 0,6 & 0 & 0 & 99,84 & 0,16 \\
\hline 0,3 & 0 & 0 & 99,84 & 0,16 \\
\hline 0,15 & 0 & 0 & 100 & 0 \\
\hline pan & 5,1 & 0,16 & 708,74 & \\
\hline Total & 3000 & 100 & & \\
\hline
\end{tabular}

Then the value of Aggregate Grain Fine Modulus (MHB)

$$
\begin{aligned}
& =\frac{\text { gh cumulative }}{100} \\
& =708,74 / 100
\end{aligned}
$$

$$
=7.08
$$

Based on the results of the fine aggregate sieve analysis

\begin{tabular}{|c|c|c|c|c|}
\hline \multirow{2}{*}{ Check } & \multirow{2}{*}{ Notation } & \multicolumn{2}{|c|}{ Sample } & \\
\hline & & $\mathbf{A}$ & B & \\
\hline SSD sand weight (gram) & A & 500 & 500 & \multirow{4}{*}{ Average } \\
\hline Pycnometer weight + sand (gram) & $\mathrm{B}$ & 1549 & 1517,1 & \\
\hline Pycnometer weight + water (gram) & $\mathrm{C}$ & 1248,9 & 1215,8 & \\
\hline Oven dry sand weight (gram) & $\mathrm{D}$ & 489,9 & 491,5 & \\
\hline Dry Density & $\frac{D}{(A+C-B)}$ & 2,45 & 2,47 & 2,46 \\
\hline
\end{tabular}
test, the MHB value obtained was 7.08 which met the SII 0052 standard, namely between $6-7,1$.

Table 3 Density Testing Results and Fine Aggregate Absorption 


\begin{tabular}{|l|c|c|c|c|}
\hline $\begin{array}{l}\text { Surface Saturated Density } \\
\text { (SSD) }\end{array}$ & $\frac{\mathrm{A}}{(\mathrm{A}+\mathrm{C}-\mathrm{B})}$ & 2,50 & 2,51 & 2,51 \\
\hline Percentage of Water Absorption (\%) & $\frac{\mathrm{A}-\mathrm{D}}{\mathrm{D}} \times 100 \%$ & 2,062 & 1,729 & 1,895 \\
\hline
\end{tabular}

Based on the results of the calculation of density and absorption of fine aggregate, the dry density value is
2.46; SSD specific gravity of 2.51; and absorption of $1,895 \%$.

Table 4. Density Testing Results and Coarse Aggregate Absorption, Size 1/2

\begin{tabular}{|c|c|c|c|c|}
\hline \multirow{2}{*}{ Check } & \multirow{2}{*}{ Notation } & \multicolumn{2}{|c|}{ sample } & \\
\hline & & $\mathbf{A}$ & B & \\
\hline SSD coarse aggregate weight (gr) & A & 1568,7 & 1464,3 & \\
\hline Aggregate Weight in water (grams) & $\mathrm{B}$ & 970,8 & 907,5 & Average \\
\hline Dry oven weight aggregate (gram) & $\mathrm{C}$ & 1538 & 1439,1 & \\
\hline Dry Density & $\frac{C}{A-B}$ & 2,572 & 2,585 & 2,578 \\
\hline $\begin{array}{l}\text { Surface Saturated Density } \\
\text { (SSD) }\end{array}$ & $\frac{A}{A-B}$ & 2,624 & 2,630 & 2,627 \\
\hline Percentage of Water Absorption\% & $\frac{A-C}{C} \times 100 \%$ & 1,996 & 1,751 & 1,874 \\
\hline
\end{tabular}

Based on the test results of coarse aggregate size $1 / 2$, the dry density results are 2.578; SSD specific gravity is 2,627 ; and absorption of $1.874 \%$.

Table 5. Content of Fine Aggregate Sludge

\begin{tabular}{|l|c|c|}
\hline \multicolumn{1}{|c|}{ Check } & Notation & Sample \\
\hline Weight of sand before washing & B & 959,1 \\
\hline Constant sand weight (grams) & $\frac{\text { A-B }}{\text { A }} \times 100 \%$ & 957,1 \\
\hline Sludge levels (\%) & & 0,21 \\
\hline
\end{tabular}




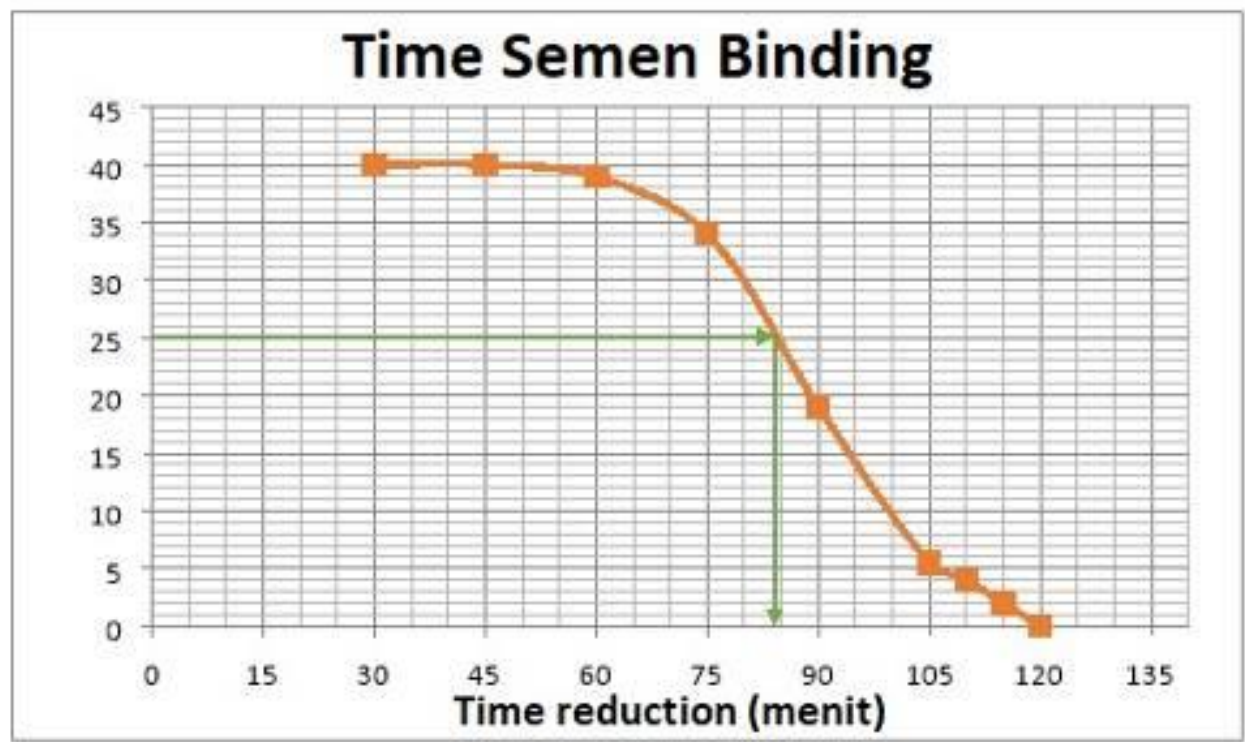

Figure 3 Cement Bonding Time Decrease Curve

Based on the results of the cement binding time test that has been carried out in the laboratory, it was found that the value of the cement binding time decreased, the initial binding time at a decrease of $25 \mathrm{~mm}$ occurred at 84 minutes and the final binding time occurred at 120 minutes with a decrease of $0 \mathrm{~mm}$.

Table 4.14 Specific Gravity of Fly Ash

\begin{tabular}{|l|c|c|c|}
\hline \multirow{2}{*}{\multicolumn{1}{c|}{ Check }} & Notation & \multicolumn{2}{c|}{ Sample } \\
\cline { 3 - 4 } & & A & B \\
\hline Pycno weight + cap (gram) & A & 50,49 & 50,64 \\
\hline Pycno weight + fly ash (gram) & B & 156,55 & 158,01 \\
\hline Pycno weight + fly ash + water (gram) & D & 147,71 & 149,26 \\
\hline Pycno weight + water (gram) & B - A & 2,401 & 2,389 \\
\hline & (D - A) - (C - B) & \\
\hline Specific Gravity of Fly Ash & & & 2,395 \\
\hline Average Density of Fly Ash & \multicolumn{2}{|c|}{} \\
\hline
\end{tabular}

\section{CONCLUSION}

In summary, the results of research concrete with partial replacement of cement with varying fly ash has a compressive strength greater than the compressive strength of normal concrete. It is possible to increase the compressive strength of concrete from the partial replacement of cement with fly ash which varies with normal concrete, namely: at the age of 7 days, the increase in the compressive strength of concrete with partial replacement of cement with fly ash which varies with normal concrete, namely at the level of addition of $6 \%$ fly ash there is a decrease in the compressive strength of $4.166 \%$ by $19.78 \mathrm{MPa}$, at the level of addition of $8 \%$ fly ash there is an increase of $2.277 \%$ is $21.11 \mathrm{MPa}$, the level of addition of $10 \%$ fly ash is still $20.64 \mathrm{MPa}$. At the age of 14 days, the increase in the compressive strength of concrete by replacing part of the cement with fly ash which varies with normal concrete is that at the level of addition of $6 \%$ fly ash there is a decrease of $5.42 \%$ by $24.60 \mathrm{MPa}$, at the level of addition of $8 \%$ fly ash there is an increase of $0,03 \%$ of $26.11 \mathrm{MPa}$, the level of addition 
of $10 \%$ fly ash is still $26.01 \mathrm{MPa}$. At the age of 21 days, the increase in the compressive strength of concrete by replacing part of the cement with fly ash which varies with normal concrete is that at the level of addition of $6 \%$ fly ash, there is a decrease of $3.799 \%$ by $29.88 \mathrm{MPa}$, at the level of addition of $8 \%$ fly ash there is an increase of $0.115 \%$ by $31.42 \mathrm{MPa}$, at the level of addition of $10 \%$ fly ash there is a decrease of $0.045 \%$ of $30.92 \mathrm{MPa}$. Finally, at the age of 28 days, the increase in the compressive strength of concrete by replacing part of the cement with fly ash which varies with normal concrete is that at the level of addition of $6 \%$ fly ash there is a decrease of $2.644 \%$ by $34.97 \mathrm{MPa}$, at the level of addition of $8 \%$ fly ash there is an increase of $0.155 \%$ by $36.48 \mathrm{MPa}$, at the level of addition of $10 \%$ fly ash, there was an increase of $0.050 \%$ of $36.10 \mathrm{MPa}$.

\section{ACKNOWLEDGMENT}

This work is supported by Ministry of Cultural and Education of Republic of Indonesia, Directoral of Vocational Higher Education, Politeknik Negeri Sriwijaya through Research Development Funding 2020.

\section{REFERENCES}

[1] Mardiono, 2011, Effect of The Use of Fly Ash Concrete in High Quality, Jurusan Teknik Sipil
Fakultas Teknik Sipil Dan Perencanaan Universitas Gunadarma Jakarta

[2] Arifin, F., Iskandar, Azharuddin, 2012, Taguchi Method Approach to Optimize Manufacturing Process Parameters of Aluminum-5\% Fly Ash Alloy Using Powder Metallurgy, Advance Material research, SSN: 1662-8985, Vol. 576, pp 284-288, doi:10.4028/www.scientific.net/AMR.576.284

[3] Danasi M., and Lisantono A., 2015, Effect of Added Fly Ash on High Quality Concreate with Silica Fume and Filler Kwarsa Sand, Preceding National Conference Civil Engineering 9 (KoNTeks 9), Makasar 7-8 October 2015

[4] Pangestuti, E.K., Handayani, S., Purnomo M., Silitonga, D.C., Fathoni M.H., 2018 The Use of Fly Ash as Additive Material to High Strength Concrete, Jurnal Teknik Sipil \& Perencanaan. Doi. 10.15294/jtsp.v20i2.16274.

[5] ACI Committee 544, 1982.State of the art on fibre reinforced concrete. ACI544,IR-82, Detroi, Michigan

[6] ASTM C618,Standart Specification for Cola fly ash an raw or Calcined Natural Pozolan for Use. Annual Book Of ASTM Standart, 3-6 doi :10.1520/C0618. 